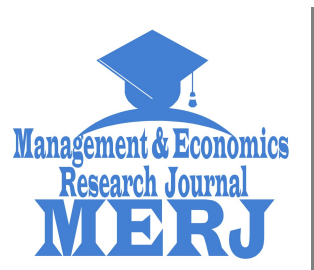

doi) https://doi.org/10.48100/merj.v1i3.42

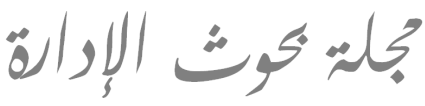

Management \& Economics Research Journal

Vol. 1 No. 3 (2019): September المجلد 1 العدد 3 (2019): سبتمبر

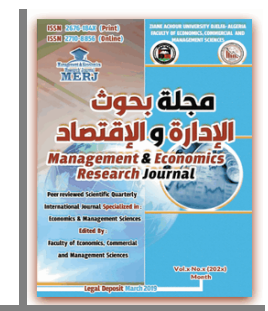

Check for updates

\title{
Impact of the IMF Loan Program on Macroeconomic Performance and Social Protection in Egypt 2016/2019
}

\author{
Mahmoud SAEED ${ }^{1 *}$ \\ ${ }^{1}$ Bachelor of Economics, The British University in Egypt (Egypt) \\ e-mail: Mahmoud192040@bue.edu.eg
}

PTIXVIXVI

Received: 20-09-2019

Accepted: $29-09-2019$

Published: 30-09-2019

\section{Abstract:}

This paper briefly investigates the impact of the participation of Egypt in the IMF loan program in November 2016 on Egyptian macroeconomic performance and social protection. It uses the (before-after) approach to measure the changes in the macroeconomic variables. All the variables are measured by using descriptive analyses. It was found that the effects of the IMF program were positive, and the macroeconomic performance along with social protection programs have significantly improved.

Keywords: IMF, Loan, Economic Growth, Egypt.

JEL Classification: G2, E00.

تبحث هذه الورقة باختصار تأثير مشاركة مصر في برنامج قروض صندوق النقد الدولي في نوفمبر

2016 على أداء الاقتصاد الكلي المصري والحماية الاجتماعية. يستخدم النهج "قبل -بعد" لقياس التغيرات في متغيرات الاقتصـاد الكلي. تم قياس جميع المتغيرات باسـتخدام التحليلات الوصـفيـة. وقـد وجـد أن آثار برنامج صيندوق النقد الدولي كانت إيجابيـة وأن أداء الاقتصـاد الكالي إلى جانب برامج الحمايـة الاجتماعيـة قد تحسن بشكل كبير. الكلمات المفتاحية: صندوق النقد الدولي، قرض، النمو الاقتصادي، مصر . تصنيف G2, E00 : JEL.

- Corresponding author: Mahmoud SAEED, e-mail : Mahmoud192040@bue.edu.eg 
Management \& Economics Research Journal Volume(01)-Issue:(03)(September 2019) P: 54-61

\section{Introduction}

In November 2016, after two years of negotiation, the Egyptian government reached an agreement with the IMF for a US\$ 12 billion loan funded over three years under the Extended Fund Facility (EFF) alongside a structural reform program. This agreement was intended to rescue the economy after a significant downward trend in all macroeconomic objectives.

This paper briefly attempts to know how the IMF that Egypt has received over the last three years has affected macroeconomic performance and social protection. It uses the "before-after" method to examine the change in each macroeconomic variable before the program's implementation and after two years and a half from the start date. Descriptive analyses are used to measure the change that happened in each variable before and after the mentioned period. Precisely, unemployment, inflation, economic growth, FDI, and the budget deficit will be measured throughout this paper by the unemployment rate, CPI, real GDP, and changes in FDI and budget deficit, respectively. Moreover, social protection will be measured by the total government expenditure on social safety.

The finding will contribute to the literature by measuring the impact of an IMF loan on the economic performance of one country and help the government take decisions to improve the economic situation further.

The remaining sections of this report are structured as follows: Section 2 takes a brief review of the previous literature. Section 3 analyzes the changes in the variables and briefly discusses the results. Section 4 concludes the paper and gives policy implications.

\section{Literature Review}

Theoretically, IMF interference can impact economic growth by "its money, the policy conditions it attaches to its loans and, more generally, its policy advice" (Dreher, 2006, p.2). The overall finding in the literature states that the IMF loan programs do not necessarily foster economic outcomes of the recipient countries (Fidrmuc \& Kostagianni, 2015).

The empirical evidence in the literature substantially varies following the sample, method, and instrument used. Przeworski and Vreeland (2000) found that countries' participation in IMF loan programs negatively affects economic outcomes. Barro and Lee (2005) have found similar positive effects using a combination of political and economic instruments. In contrast, Dicks-Mireaux, Mecagni, and Schadler (2000) conclude, using a 
sample of 74 countries, that participation in an IMF loan program positively affects the economic output.

Nonetheless, all the contributions that examined the results of IMF loan programs were conducted on a dataset containing many countries, which significantly affected the findings. This paper focuses only on one country, which will clarify the impact of IMF aid assistance on macroeconomic performance. In addition, no papers considered the effect of the loan on social protection, which will be an understudy in this paper.

\section{Data Analysis}

In this section, the changes in macroeconomic variables: economic growth, unemployment, Foreign Direct Investment, budget deficit, and inflation will be depicted and analyzed.

\subsection{Macroeconomic Performance}

Fig.1: Changes in Macroeconomic Performance in Egypt since the start of the IMF

\section{Program}

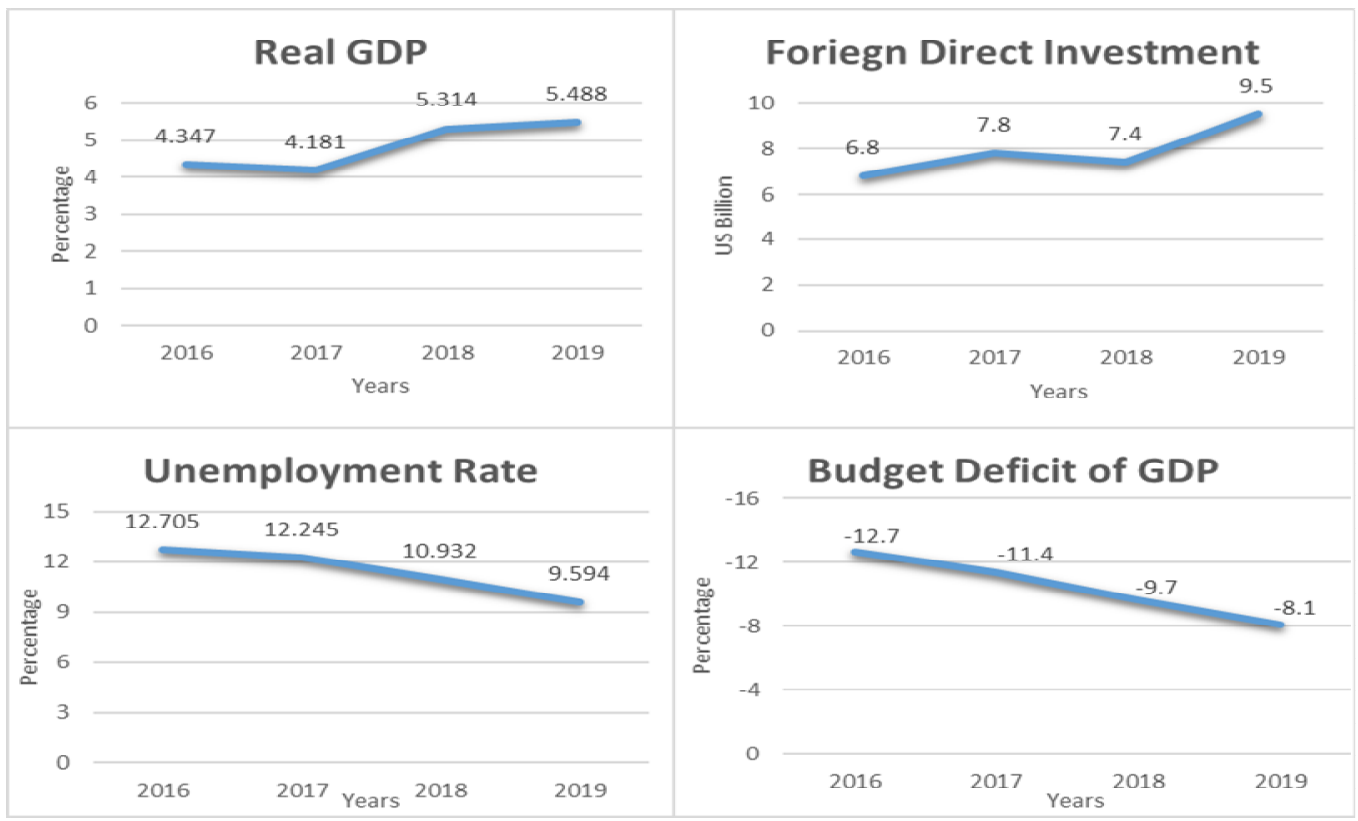

Source: (IMF, World Economic Outlook Database, April 2019). 
Management \& Economics Research Journal Volume(01)-Issue:(03)(September 2019) P: 5461

As depicted in Figure 1, economic growth has been accelerating since and during the program's implementation, rising from 4.3 in 2016 to 5.5 in 2019, and it is projected to reach 5.9 at the start of 2020 (IMF,2019). Foreign Direct Investments (FDI) rose dramatically till 2018 when it experienced a slight decline, then it increased substantially to reach $\$ 9.5$ billion in 2019.

Moreover, the unemployment rate has been steadily decreasing throughout the program, declining from $12.7 \%$ before the program's start to $9.5 \%$ in 2019 , the lowest percentage since 2011. The budget deficit has been on a downward trend since 2016, as it was the main objective behind the program. It has decreased from 12.7 per cent of GDP in 2016 to 8.1 per cent in 2019.

Fig. 1: Changes in Inflation Rate over the period of the Program

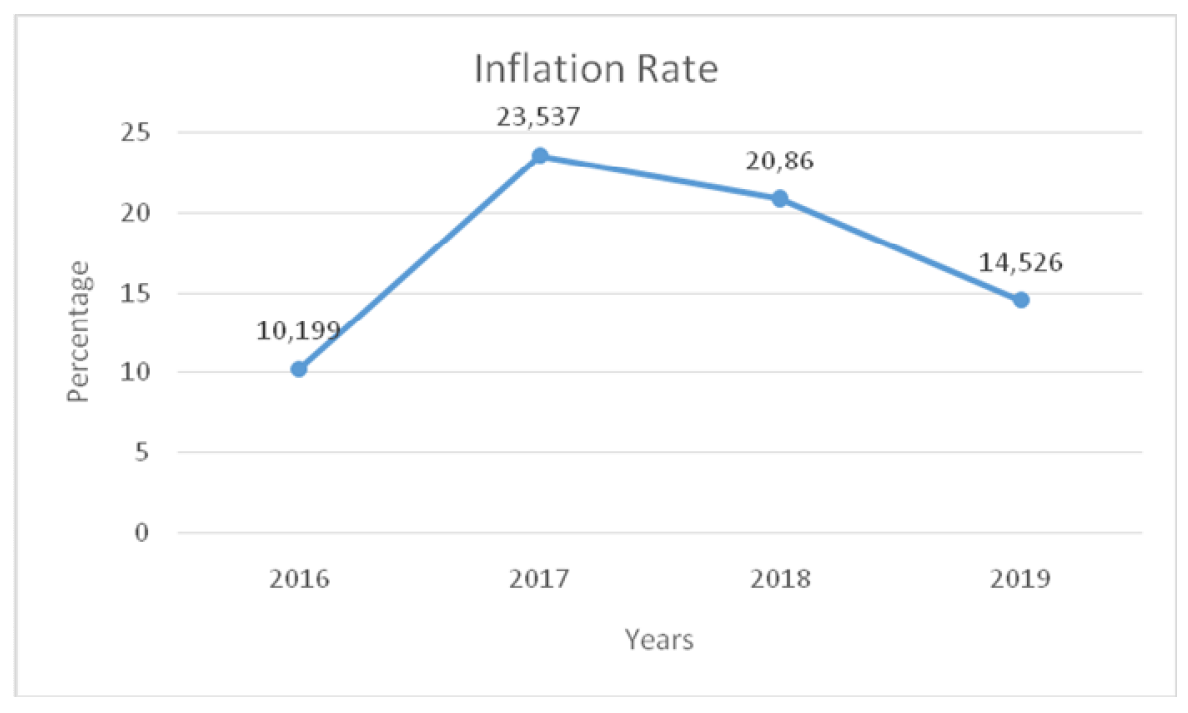

Source: (IMF, World Economic Outlook Database, April 2019).

As a consequence of the reform program that accompanied the IMF loan, the inflation rate has fluctuated since the program started. The reform program - which was carefully planned to mitigate the anticipated negative effects out of the adjustments- required the government to reduce the huge energy subsidies, which, in turn, raised the prices of energy products. This price surge caused inflation to accelerate substantially in 2017 to around 33 per cent in June. Since then, it decreased dramatically to reach 14 per cent in 2019. 
Mahmoud SAEED Impact of the IMF Loan Program on Macroeconomic Performance and Social Protection in Egypt 2016/2019

\subsection{Social Protection}

Recently, the IMF reported in its final review of the Egyptian loan program that authorities in Egypt have opted for "expanding the number of better-targeted social programs. These programs include cash transfer programs, programs to help the unemployed find jobs, programs to provide women with microcredits, and programs to provide access to clean drinking water and sanitation" (IMF, 2019). Hence, the overall government expenditure on social protection has significantly accelerated since the start of the program to compensate for the negative consequences of the reform program, as depicted below in Figure 3.

Fig.1: Government Spending on Subsidies, Social Benefits, and Grants

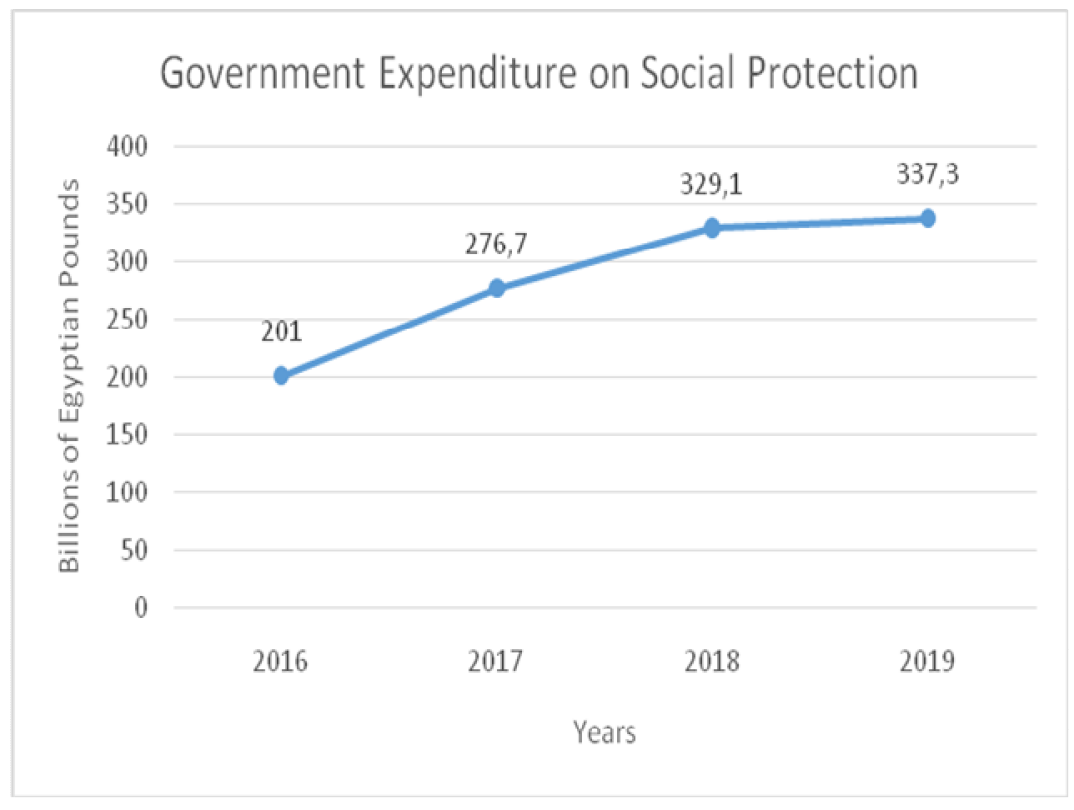

Source: (IMF Report, April 2019). 
Management \& Economics Research Journal Volume(01)-Issue:(03)(September 2019) P: 54-61

\section{Conclusion}

The analyses have depicted the credibility of Christine Lagarde's statement that Egypt has attained crucial progress on the macroeconomic and social protection levels. The overall macroeconomic performance in Egypt has been improving since the program's start. A high growth rate has been achieved, Foreign Direct Investments have increased, unemployment has been reduced to its lowest rate since the revolution in 2011, the budget deficit is on a downward track, and inflation is projected to decline further this year. Furthermore, the government expenditure on social protection programs has witnessed a crucial surge.

This finding agrees with Barro and Lee (2004) that the effects of IMF programs are positive and might agree with Joyce (2004) and Binder and Bluhm (2014) that the results vary in response to the commitment toward the program's conditions.

While conducting this report, several unavailable and inaccurate data were encountered. No available data on government expenditure on social protection was found in the government's official sources, so the IMF report was the primary source for such data. Inflation data is not generally precise because of the fixed and outdated basket of goods and services used in calculating inflation.

This report was prepared to examine the claim of Christine Lagarde's statement that the IMF program has positively affected Egyptian macroeconomic performance and expanded social protection coverage. After analyzing changes in macroeconomic variables and government spending on social safety, it is apparent that real GDP and FDI showed a significant increase, budget deficit and unemployment are on a downward trend, and inflation is declining. In addition, the total government spending on subsidies, grants, and social benefits has substantially accelerated over the preceding three years.

Nonetheless, the gross debt is still high, and the social protection programs do not fully cover all the negatively affected households. Hence, it is proposed for the government to:

- Cut off loans and increase progressive taxes to repay the debts.

- Continue implementing the program at "the planned pace given the large remaining gap between retail prices and cost recovery" (IMF, 2018).

- Further, use the revenues from taxes to increase the expenditure on social protection(ILO, 2017). 


\section{References}

Barro, R. J. \& Lee, J. W. (2005). IMF-Programs: Who Is Chosen and What are the Effects? Journal of Monetary Economics, 52 (7), 1245-1269.

Binder, M., \& Bluhm, M. (2014). On the Conditional Effects of IMF Loan Program Participation on Output Growth (No. 78). IMFS Working Paper Series.

Dicks-Mireaux, L., Mecagni, M., \& Schadler, S. (2000). Evaluating the effect of IMF lending to low-income countries. Journal of Development Economics, 61(2), 495-526.

Dreher, A. (2006). IMF and economic growth: The effects of programs, loans, and compliance with conditionality. World Development, 34(5), 769-788.

Fidrmuc, J., \& Kostagianni, S. (2015). Impact of IMF assistance on economic growth revisited. Economics and Sociology, V (8) 3.

Hajro, Z., \& Joyce, J. P. (2009). A true test: do IMF programs hurt the poor? Applied Economics, 41(3), 295-306.

International Labor Organization. (2017). Executive Summary: World Social Protection Report. Retrieved from: http://www2.ilo.org/public//english/protection/socfas/publ/tcrep/egypr16.pdf International Monetary Fund (IMF). (2018). Arab Republic of Egypt: Review Under the Extended Arrangement Under the Extended Fund Facility, And Requests for A Waiver of Nonobservance of a Performance Criterion and Modification of a Performance Criterion-Press Release; Staff Report; And Statement by The Executive Director for The Arab Republic of Egypt. Retrieved from: https://www.imf.org/en/Publications/CR/Issues/2018/07/12/Arab-Republic-ofEgypt-Third-Review-Under-the-Extended-Arrangement-Under-the-Extended-Fund46061

International Monetary Fund. (2019). World Economic Outlook Database. Retrieved from: https://www.imf.org/external/datamapper/datasets/WEO

International Monetary Fund. The Middle East and Central Asia Dept. (2019). Arab Republic of Egypt: Fourth Review Under the Extended Arrangement Under the Extended Fund Facility-Press Release; Staff Report; and Statement by the Executive Director for the Arab Republic of Egypt. Retrieved from: 
Management \& Economics Research Journal Volume(01)-Issue:(03)(September 2019) P: 54-61

https://www.imf.org/en/Publications/CR/Issues/2019/04/05/Arab-Republic-of-

Egypt-Fourth-Review-Under-the-Extended-Arrangement-Under-the-ExtendedFund-46738

Przeworski, A. \& Vreeland, J. R. (2000). The Effect of IMF Programs on Economic Growth. Journal of Development Economics, 62, 385-421.

How to cite this article by the APA method:

Saeed, M. (2019). Impact of the IMF Loan Program on Macroeconomic Performance and Social Protection in Egypt 2016/2019. Management \& Economics Research Journal, 1(3), 5461. https://doi.org/10.48100/merj.v1i3.42

The copyrights of all papers published in this journal are retained by the respective authors as per the Creative Commons License.

Management \& Economics Research Journal is licensed under a Creative Commons Attribution-Non Commercial License (CC BY-NC 4.0). 